$\xi=-1$

\title{
Establishment of share unit formula for strata residential buildings and its implication to buyer and unit owner
}

\author{
Rubiah Md Zan ${ }^{a *}$, Dr Siti Nur Alia Roslan ${ }^{a}$, Nur KhairulFaizah Mustafa ${ }^{a} \&$ Asma Senawi ${ }^{b}$ \\ ${ }^{1,2,3}$ Faculty of Architecture and Built Environment, Infrastructure University Kuala Lumpur, Kajang, Selangor, Malaysia \\ ${ }^{4}$ Faculty of Architecture, Planning and Surveying, Universiti Teknologi MARA, Seri Iskandar Campus, \\ Sri Iskandar, 32610, Perak, Malaysia \\ *Corresponding author E-mail: rubiah@iukl.edu.my
}

\begin{abstract}
Stratified development has become a trend nowadays and still expanding to suit with the scarcity of land. During the implementation of the early Strata Titles Act, there are many issues and disputes raised in terms of its legislation, rule and regulation, implementation, management and maintenance. One of the issues is the establishment and implementation of share unit formula to strata building. Recently, the government of Malaysia has formulated and approved the new Act which is called the Strata Management Act 2013 whereby several amendment has been made to strengthen and improve the current exercise and give a new breath to strata building development. The objective of this paper is to study the establishment of Share Unit Formula for strata residential building in Klang Valley and the implication of the new provision to house buyers and unit owners. A quantitative survey has been done by conducting interviews with the professionals in the industry. The findings of the research revealed that there are many advantages obtained by the house buyers and unit owners due to the latest enforcement. Besides promotes transparency and accountability in the housing development industry, it is also help to encourage an efficient application of simultaneous vacant possession of Strata Title to the unit buyers.
\end{abstract}

Keywords: Establishment; Share Unit Formula; Strata Management Act 2013 (Act 757); Implication; Buyer and Unit Owner

\section{Introduction}

Over the years stratified buildings especially in the Klang Valley and other major cities have mushroomed as a testimony to the Malaysia's prosperity and development. In Malaysia, multi-storey buildings are considered strata type of development. Some choose to own a strata unit especially condominium due to the luxury of extensive facilities and services provided, as well as the high prestige bestowed to this new modern living concept while some were forced to buy high rise units as they cannot afford to buy landed property. Looking at the housing development trend, the problems on the management of high rise residential buildings has become a serious issue in the country since the Stata Title Act (1), Act 318 imposed. The STA 1985 sets to regulate the registration of strata titles and the day to day operation of strata management and maintenance. Various complaints from the parcels owners or residents of stratified residential building pertaining to the management of their building have been increasing from day to day. During the implementation of the early Strata Titles Act, there are many issues and disputes raised in terms of its legislation, rule and regulation, implementation, management and maintenance. One of the issues is the establishment and implementation of Share Unit formula to strata residential building which resulted to delay in title issuance, neglect from developer, improper information on building development, poor management etc. Almost every day we come across, at least, one article related to the problems in strata living, particularly in the low and medium cost schemes where the developers and other related parties tend to run away from solving the issues. Therefore, this paper objectives are to study the establishment of Share Unit Formula for strata building in Klang Valley and to identify implication of the new provision of Share Unit formula to house buyers and unit owners.

\section{Literature Review}

\subsection{Stratified Building Management and Introduction to Share Unit}

Stratified residential properties are becoming the choice of developers in urban areas due to land scarcity and high land prices. Stratified property development maximizes density within the allowable planning standards $(2,3)$. Land matters in Malaysia always refer to National Land Code enacted and consolidate the laws relating to land, land tenure, registration of title, land dealing etc. Construction of condominium, apartment, flats and high-rise building in in the urban areas such as Kuala Lumpur, Johor Bharu and Penang is a phenomenon due to scarcity of land and high land costs. Strata Title is a document of title which endorsed by the land administrator for the whole parcel of a subdivided building (4). As the number of stratified building increasing, issues related to high-rise or stratified buildings are increasing as well. Throughout years of implementation of the Strata Titles Act 1985 (Act 318 ) it is seen unable to resolve issues. Many problems have created in strata title type of residential which required Management Corporation (MC) in managing and maintaining the strata buildings (5). In 2007 the government formulated and approved the Building and Common Property (Maintenance and Management) Act 2007 (Act 663) to provide framework for the establishment of Joint Management Body (JMB) and the appointment of Commis- 
sioner of Building (COB) to administer the Act. The act is now replaced by the new Act which is called the Strata Management Act 2013, Act 757 (6).

The concept of high-rise or stratified residential is not something new in Malaysia, the purchaser will be provided with variety of amenities and facilities for each of the development to attract buyers. The buyer will be liable to pay for service charges for the management and maintenance of the common properties (3). Unfortunately, the misconception of sharing facilities and sharing responsibilities towards the payment of maintenance fees become the major issues of defaulters and huge outstanding amount of maintenance fees (7). The share unit element was first introduced in Act 318 as to require the collection of maintenance and management charges collected in proportion to the "Allocated Share Units". Unfortunately there is no details explanation on the establishment of the Share Unit formula in the Act. The Share Unit definition is the number assigned to each parcel by the developer's licensed land surveyor to determine the maintenance charges, sinking fund and other outgoings, to be paid by each parcel owner in an equitable and transparent manner. Based on the improvement of the provision, the Share Units are computed based on area, usage, size and location of the accessory parcel using the prescribed formula under the First Schedule of Strata Management Act 2013 (6). Share Units shall be determined before any sale so that purchasers aware the onset of their share of payment to the building. The payment of the maintenance fees also applicable to developers with unsold units. Each parcel is allocated with share unit and is shown on the strata plan. The owner of a penthouse will have bigger share units, thus more voting rights as compared to an owner of an intermediate unit. A parcel owner with a bigger share unit will have to pay higher maintenance charges.

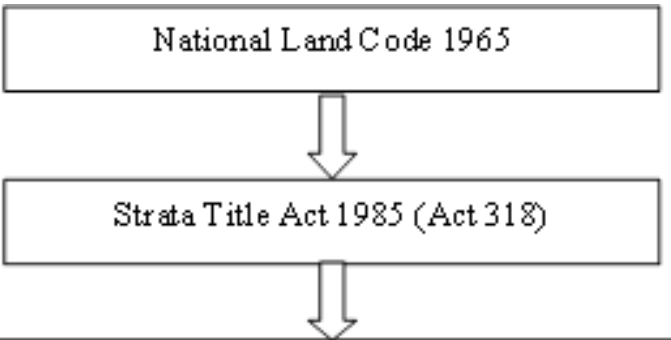

Building and Comm on Property (Managem ent and Maintenance) Act 2007 (Act 663) (Repealed)

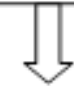

Str ata Management Act 2013 (Act 757)

Fig 1: Flowchart of Strata Act Introduced in Peninsular Malaysia

\subsection{New Rules for Share Unit Formula Gazetted in Strata Management Act, 2013}

The Section 6 of the new SMA 2013 stated that it is compulsory that a developer cannot sell any parcel from stratified properties whether commercial or residential building unless the Schedule of Parcels has been filed with the Commissioner of Building (COB). Thus, it is incumbent upon the developer's licensed land surveyor and registered architect to certify that the building or land is capable of being subdivided. There has also stated a developer has to display the Schedule of Parcels in a conspicuous location at the point of sale so that purchasers know what they are getting eventually especially information relating to the size of the unit, size of accessory parcel, share unit and the maintenance charges amount for the unit. With the share units being calculated according to the First Schedule of the SMA 2013, sharing of responsibility in maintaining the common areas will be more equitable and trans- parent. Local Authority and Land Office have implement a system and certification of share unit determination for Strata Development in Malaysia. This system would require the licensed land surveyor to apply for the certification. Upon approval of the certificate from the Land Office, it then will be submitted to COB at Local Authority before commencement of the ground work.

\subsection{Formula Computation of the Allocated Share Unit of Parcel}

The share units of a parcel are the area of that parcel multiplied by the weightage factor for that type of parcel and the weightage factor for the entire floor parcel. If there is any accessory parcel, the area of the accessory parcel is multiplied by a weightage factor for that accessory parcel. If there is more than one accessory parcels, the formula for calculation shall be applicable to each accessory parcel and it shall then be added accordingly. Both the value of the parcel and accessory parcel shall be added to determine the total share units.

The formula is as follows:

Table 1: Unit Share Formula

\begin{tabular}{|l|}
\hline $\begin{array}{l}\text { Share units of parcel }=(\mathrm{A} \times \mathrm{F} 1 \times \mathrm{F} 2)+(\mathrm{B} \times \mathrm{F} 3) \\
\text { Share units of land parcel }=(\mathrm{A} \times \mathrm{0} \text { ) } 8)+(\mathrm{B} \times \mathrm{F} 3)\end{array}$ \\
\hline Source: Strata Management Act 2013, Act 757
\end{tabular}

The calculation of share unit consist of two formula which are the formula for share unit of parcel and share units of land parcel. The difference between these two formulas is that the share unit of parcel is used to calculate the share unit for standard high-rise strata building while the share unit of land parcel is used for strata landed property which implements the concept of gated and guarded residential type. For the share unit of parcel; there are TWO (2) variables to derive to the share unit amount. Variables number one is A where it is presented as area of the parcel times with both $\mathrm{F} 1$; the weightage for the type of parcel as specified in Schedule A and F2;the weightage for the overall floor parcel as specified in Schedule B. The total will be accumulated with the second variable, Variable B where the area of the accessory parcel times with F3; the weightage for the accessory parcel as specified in Schedule C.

For the calculation of share unit of land parcel, there are also TWO (2) variables involves, variable number one is A; where it is presented as area of the parcel times with 0.8 while variable number two is B where the area of the accessory parcel times with F3 which actually the weightage for the accessory parcel as specified in Schedule C. Total amount will be accumulated to form the final share unit amount. The total number of 100 units is assumed in Table 2, below as according to (4), based on Dewan Bandaraya Kuala Lumpur statistic on FABIABCIA Malaysia \& PPK Seminar (2008) stated that the total number of strata development project for the whole Malaysia at that time was 9,319 residential projects with total of $1,232,848$ parcel units which is equivalent to 100 units per project. This formula will thus become the foundation of SiFUS which refer to the certificate of share unit formula.

Table 2: Table Calculation of the Share Unit Formula

\begin{tabular}{|l|l|c|l|}
\hline No & $\begin{array}{c}\text { Type of } \\
\text { Development }\end{array}$ & $\begin{array}{c}\text { Total } \\
\text { Parcel } \\
\text { Unit }\end{array}$ & \multicolumn{1}{|c|}{ Share Unit Calculation } \\
\hline 1 & Residential & 100 & $\begin{array}{l}\text { a) Floor Area of parcel x Factor 1 } \\
\text { b) (Area or parcel) } \times(1) \times(1)+ \\
\text { (Area of } \\
\text { accessory parcel) } \times(0.25)\end{array}$ \\
\hline 2 & Commercial & 100 & $\begin{array}{l}\text { (Area of parcel) } \times(0.85) \times(1)+ \\
\text { (Area of accessory parcel) } \times(0.25)\end{array}$ \\
\hline
\end{tabular}


Table 3: Sample computation of the share unit formula

\begin{tabular}{|c|c|c|c|c|c|c|c|c|c|c|c|}
\hline $\begin{array}{c}\text { To } \\
\text { we } \\
\text { r }\end{array}$ & $\begin{array}{l}\text { L } \\
\text { ev } \\
\text { el }\end{array}$ & $\begin{array}{c}\text { Pa } \\
\text { rc } \\
\text { el }\end{array}$ & $\begin{array}{c}\text { Ar } \\
\text { ea/ } \\
\text { A } \\
\left(\begin{array}{c}M \\
2\end{array}\right)\end{array}$ & $\begin{array}{c}\text { Use } \\
\text { of } \\
\text { Par- } \\
\text { cel }\end{array}$ & $\begin{array}{l}\mathbf{F} \\
\mathbf{1}\end{array}$ & $\begin{array}{l}\mathbf{F} \\
\mathbf{2}\end{array}$ & $\begin{array}{c}(\mathrm{AxF} \\
\mathbf{1 x F 2} \\
)\end{array}$ & $\begin{array}{c}\text { Ar } \\
\text { ea/ } \\
\text { B } \\
(\mathbf{M} \\
2)\end{array}$ & $\begin{array}{l}\mathbf{F} \\
\mathbf{3}\end{array}$ & $\begin{array}{l}\text { (A) } \\
\mathbf{x F} \\
\mathbf{3})\end{array}$ & $\begin{array}{c}\text { U } \\
\text { nit } \\
\text { Sh } \\
\text { ar } \\
\text { e }\end{array}$ \\
\hline B & 10 & $\begin{array}{c}67 \\
7\end{array}$ & 82 & $\begin{array}{c}\text { Apar } \\
\text { tmen } \\
t\end{array}$ & 1 & 1 & 82 & 15 & $\begin{array}{l}0 . \\
2 \\
5\end{array}$ & $\begin{array}{c}3.7 \\
5\end{array}$ & $\begin{array}{c}85 \\
.7 \\
5\end{array}$ \\
\hline
\end{tabular}

\subsection{Procedures of Strata Title Application Prior to Va- cant Possession}

According to the development process in Malaysia, the housing project begins with the land acquisition stage and ends with selling of housing built. Planning control comes in at the process of getting statutory approval when application is submitted to the local planning authorities and Land Office (9). For stratified building the latest provision in SMA 2013, Act 757 has stated that with the new provision, there will be new rules where the Strata Title will be issued simultaneously at the end of vacant possession stage. Figure 2 shows the Flowchart of Strata Title Application Prior to Vacant Possession for strata building as per the guideline processes on SiFUS \& Strata Title produced by REDHA Version 02 (10). For any new development after implementation of SMA 2013, developer who involves in development of strata building in the country will obtain a planning permission upon the approval by Local Authority. Planning permission is the early step during preliminary stage before construction start. After obtaining planning permission, developer will then submit Building plan to the Local Authority for approval. The submission of building plan is important in a form of architect drawing to present a design idea and concepts of the development before construction commence by building contractor. At this stage will continue to apply project number from Jabatan Ukur dan Pemetaan (JUPEM).

The next stage after obtaining project number, develop will engage a registered land surveyor to prepared all required documents and calculation as stipulates in the STA. The calculation of share unit formula will be done in details by land surveyor and submit to Land Office. Upon receiving a complete documentation from land surveyor, the Land Office will check and investigate the draft document before approval and endorsement. Developer or Land Surveyor will required to submit 6 sets of documents including, all relevant land issues are settled such as land conversion of that site, payment of land premium, status of Title, etc. They must also provide the proof of receipt of payment for Land Premium if related, an approval letter for qualified Title application certificate by Land Office. This is only applicable if the land is held under Qualified Title or Final Title yet to be issued. Proof receipt of Quit Rent for the current year, any letter of appointment of Licensed Land Surveyor which will be involved in the development project, proof receipt of surveying fees paid to Land Surveyor Board, the document of Share Unit formula which has been approved by Land Office. If there is any changes due to any amendment to Building Plan which has been issued with SiFUS, new application must be submitted to the Land Office for approval and new certificate will then be issued. Besides that, other document that required is Schedule of Parcels signed by Licensed Land Surveyor and Architect or Engineer and finally the Approved Building Plan. All plans must be signed by Licensed Land Surveyor (LLS) and architect. Once the application approved by the Land Office, developer will lodge SiFUS and submit another 6 sets of Schedule of parcel to COB. Upon approval, COB will acknowledge and retain 1 set of Schedule and distribute other sets to developer, The Land Office and JUPEM. A complete documentation will be accepted while approved SiFUS certificate would be issued immediately by the Land Office. SiFUS refers to the Certificate of Share Unit Formula which will be issued by Land Office prior to the commencement of sale of strata properties. The objectives of the new provision are to ensure the application process of Strata Title can be carried out smooth and efficient. As the SiFUS certificate approved and issued, the developer would then file for Schedule of parcel to COB department at Local Authority. Schedule of Parcels is a document shows the proposed share units of each parcel or proposed parcel and the total share units of all the parcels. In the case of a phased development, the schedule of parcel shows the proposed quantum of provisional share units for each provisional block. Total share units of all parcels, including provisional block, is normally referred to as the aggregate. Schedule of Parcels (SOPs) must be filed with the COB before the developer can sell any parcel or proposed parcel under S.6 (1) SMA 2013. The new regime of law requires the developer to comply with all the prerequisites before proceeding with any sales of the parcel. The major pre-requisite requirements include the payment of all premiums and fees to the relevant authorities and bodies; land and strata title survey; approval of building plans and allocation of share units. The SOPs are prepared by developer's licensed land surveyor, comprising of location plan, storey plan and delineation plan which drawn based on approved building plans. It shall show all the parcels with dimensions, areas, share units, all accessory parcels, common properties using the same format as approved strata title plans. The developers cannot simply exclude out any common property and accessorized as they like which frequently happened and reported previously. Under S.6 (3) of SMA, developer's licensed land surveyor and registered architect have to certify on the SOPs that the buildings or lands shall be capable of being subdivided.

The next step is for developer to apply for advertisement permit or developer's license from Ministry of Urban Wellbeing, Housing and Local Government (KPKT). The authority will not issue any permit unless all documentation including SiFUS certificate at the earlier stage is approved and satisfied. Upon the issuance of the permit, the developer would then allow to do marketing and sale to the public. Construction will also start to commence at this stage. As the construction entering the superstructure stage, developer would next apply for certificate of completion and compliance (CCC) along with Strata Title. Strata Title is a certificate issued by Land Office to the owner or purchaser of unit parcel to prove their ownership of the unit. Developer is responsible to apply for the Strata Title as their obligation toward the project and purchaser. The application will be done at the Land Office and Strata Roll will be filed accordingly. The final strata title will be issued to purchaser at the early stage of vacant possession.

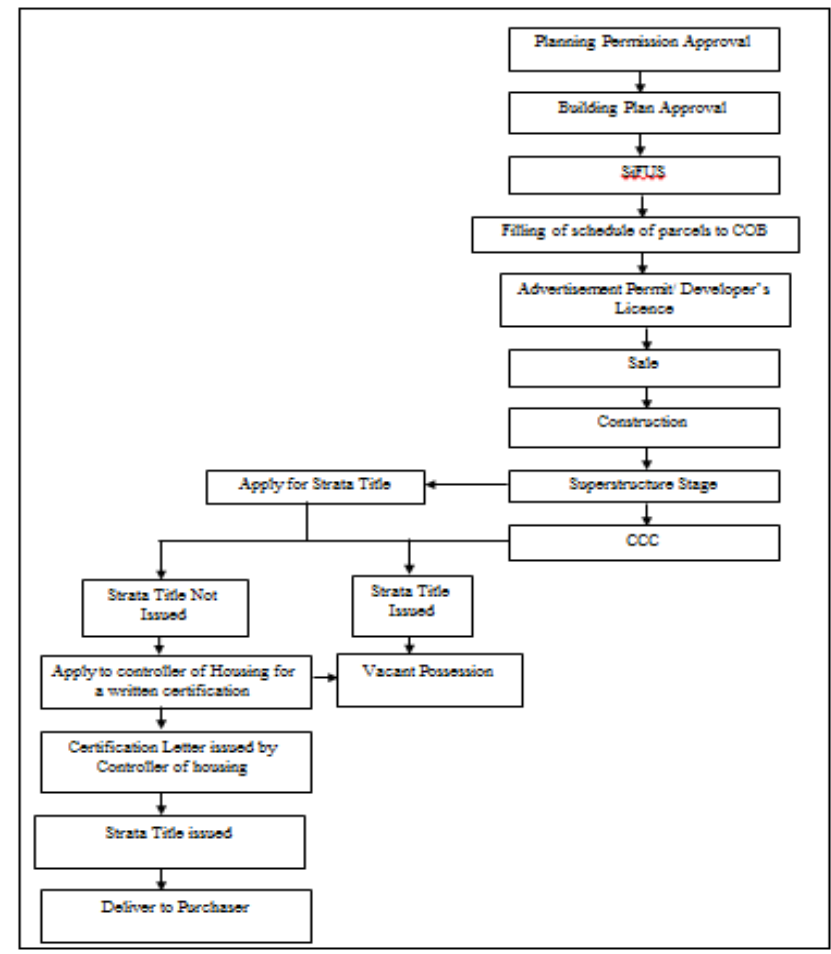

Fig 2: Flowchart of Strata Title Application Prior to Vacant Possession 


\section{Methodology}

\subsection{Research Methodology Framework}

This research is a quantitative research study where primary data and secondary data are used for data collections. For primary data, interview survey was carried out which involves authority and housing society while relevant articles on strata management was selected for secondary data collection. Through this study there are two (2) objectives to be achieved. To study the establishment of Share Unit Formula for strata building in Klang Valley and to identify implication of the new provision of Share unit formula to house buyers and unit owners. Based on Figure 3 below, there are five (5) stages applied in the research methodology framework. The method was adapted from the book, dissertation research and writing for construction students by (11). Based on the framework, Stage 1 is the earlier stage where problem statement were identified where the issues of the late issuance of strata title and the new implementation of the new Share Unit Formula implemented in the new strata development process in Malaysia. From there, two objectives were obtained and the scope of the study was established as a limitation to the research. This research focusing on Klang Valley area where most of strata developments located here. Stage 2 basically is a stage where it involves reading and critically appraising what other people has written from the previous researches.

Next is Stage 3 where data collection were obtained through structured interview survey where questions were presented in the same order and with the same wording to all the interviewees. The interview survey had implemented the in-depth group interviews where respondents were selected because of the topic and their wide knowledge in strata development process (12). Targeted group for this research including professional authorities and industry players are chosen as they have knowledge in stratified Act implemented in Malaysia and clearly understand the new provision of share unit formula. The main respondents are authority bodies including officer at Local Authority offices, Land Office, Ministry of Urban Wellbeing, Housing and Local Government (KPKT) and practitioners. It can be concluded that the data collection through a combination of standardized interview survey and secondary data collection from the Act, and books is the best method for the purpose of this research. 100 respondents were contacted from the earlier data collection stage where only 52 respondents were completely reverted the response to us.

Stage 4 is the analysis of data collection which were collected from the previous stage. All analysis was done through descriptive statistical analysis using frequency distribution where analysis was conducted using SPSS software programme and discussions were presented at this stage as to explain reasons for all feedback from the interview session (13). The final stage of the methodology is the Stage 5 where it represent the final finding and conclusion of this research.

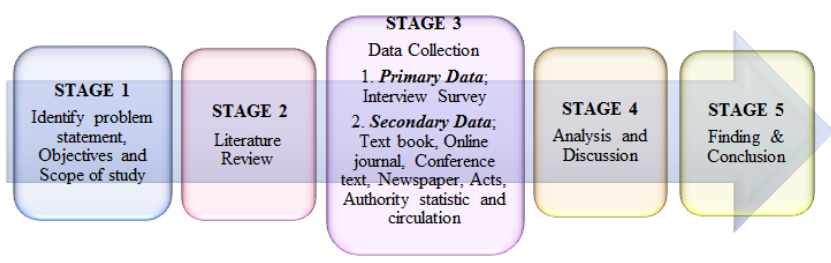

Fig. 3: Research Methodology

\subsection{Frequency Analysis}

Frequency Analysis depends on the percentage of respondents giving the same answers. It is used to measure the degree of agreement for certain statements in this research. The formula of Frequency Analysis is as follows;

Percentage $(\%)=\mathrm{n} / \mathrm{N} \times 100 \%$

Where:

$\mathrm{n}=$ no of respondents

$\mathrm{N}=$ Total number of respondents received

\section{Analysis}

For the analysis part, there are TWO (2) sections of question that has been asked during the interview session. The first part of the section is to identify the respondent profile while the second section is to test respondents' understanding on the Share Unit Formula and its implementation throughout experiences and involvement in their professional practices.

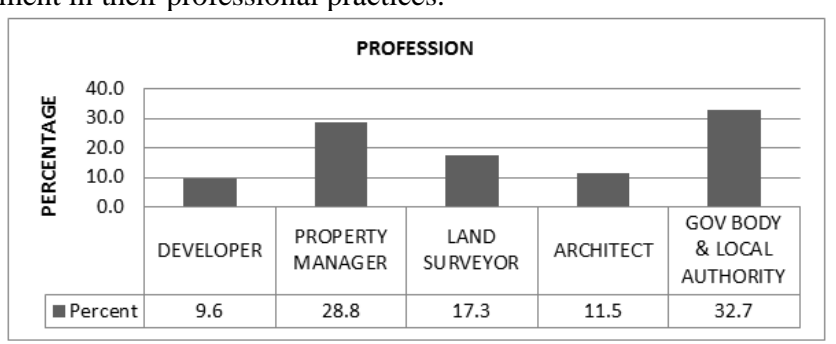

Fig. 4: Professions involved in interview survey

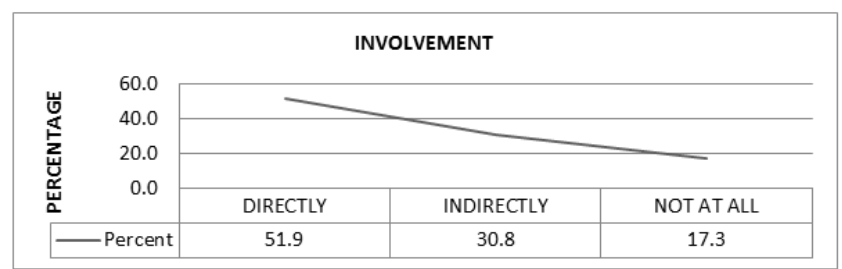

Fig. 5: Respondents' involvement in SiFUS and Strata Title Application

Respondents were from different backgrounds to participate in the research survey. From the feedback received, half of the total respondents are servicing the government sector while the rest are practitioners from the private sector. Based on the above Figure 4 shows that we have obtained a lot of input on SiFUS procedures from professionals for this research purposes. The highest respondents are those government officers from government body and local authority at $32.7 \%$ followed by property manager $28.8 \%$, land surveyor $17.3 \%$, architect $11.5 \%$ and developers $9.6 \%$. Based on the literature review and supported by result from respondents in Figure 5 these are the professionals that involve directly and indirectly in SiFUS and Strata Title application as stipulates in the SMA 2013, Act 757. Directly involved means that the person play a role or duty in the whole application procedures as stated in Figure 2 example Developer, Land surveyor, Architect and Government Body \& Local Authority while indirect involvement where the person involve after approval or issuance of the title example property manager and government body \&local authority. In the event of application been rejected the process will be extended and amendment will be required in order to proceed (10).

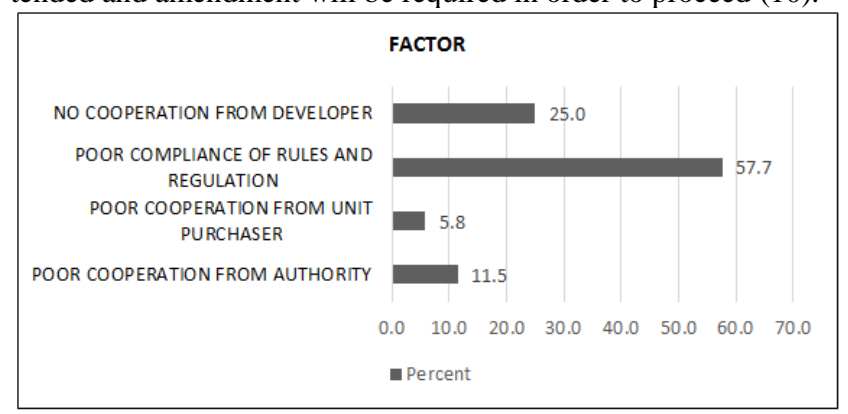

Fig. 6. Factors that caused late issuance of Strata Title to Purchaser

Based on Figure 6 above, there are several factors that might be reasons for late issuance of Strata Title to purchaser in Malaysia. 
This is not a new issue as it has become frightening to many strata unit purchaser and owners as some have to wait for years for this to happen. The figure above shows $57.7 \%$ of respondents agreed that poor compliance of rules and regulation is the major factor that caused the late issuance of the Strata Title (4). Followed by no cooperation from developer $25.0 \%$ where according to Nicole Tan and Sumathi murugiah in (2007), many cases reported developer fail or taking longer time to apply for Strata Title as they had gone bankrupt which left the building with outstanding application (14). Furthermore, $11.5 \%$ shows poor cooperation from authority as respondents blamed authority for delaying the approval process as according to Kamaruzzaman et al. (2010) improper documentation as stated in section 9 and 10 of STA 1985 is another issue which resulted late issuance of the title (1). The lowest response was $5.8 \%$ where respondents choose poor cooperation from unit owner as the factor where their ignorance on their right and responsibilities on usage of the common property as well as payment of maintenance fees that caused the delay (15). Enforcement on penalty for project delay would encourage the developer to focus on their completion stages and delivery period as to avoid the penalty.

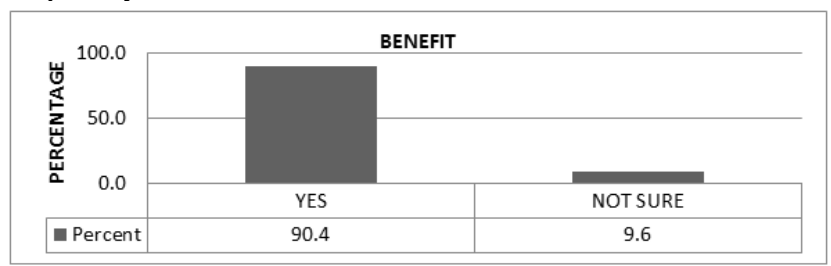

Fig 7: The benefit of new provision to buyers and unit purchaser

Based on Figure 7 above, result shows the respondents' perception on the benefit of the new provision in SiFUS and Strata Title application. From the result, $90.4 \%$ of the professional respondents agreed that the new change in provision and regulation is a new hope for purchaser and unit buyer as it would benefit them eventually.

\section{Implication}

Firstly, as discussed earlier Strata Title is a proof of ownership of stratified building own by unit owners or purchasers. In the absence of the title the owner or purchaser are the most suffer as they would not have the right to indefensibility of title provide by the National Land Code 1965. Hence, there is no security of ownership (16). There are several positive implications that can be obtained on the establishment of share unit formula for strata residential building. The latest provision on the application procedure would solve the late issuance of Strata Title and project abandonment by developer. This is because the latest application procedure is the standard of practice (SOP) for government and local authority to ensure the progress of the project and guaranteed the title to be delivered to purchaser at the stage of Vacant Possession. Furthermore, it also helps to combat any fraud cases that might happen throughout the application. Developer with poor performance and bad reputation have to be suspended from applying approval for their next project.

Secondly, interest of future buyers and unit owners are protected where the issuance of Strata Title at vacant possession will help to reduce the number of project delay. Initially when the concept of strata building first introduced, many financier were reluctant to fund the purchase and they are very careful in giving out loans where they will look for the reputation of the developer before loan approval. (16). Besides that, dealing without Strata Title is complicated procedure where the purchaser has to face the developer for them to verify the ownership of the unit to ensure the latest registered ownership record and approval have to be obtained as the master title is still registered under the developer's name. This has resulted multitude of problem thus many people would choose to purchase property with Strata Title thus the de- mand increase the property prices higher compared to strata building without individual title.

Furthermore, it also a good chance for owner and purchaser to form MC earlier upon the opening of strata register at Land Office. According to Tan Ai Leng from The Edge Market online in their latest news in September 2017 stated that property without the Strata title, the building would not be able to form JMB or MC and would require to appoint liquidator for Strata Title application (15). Lastly the new provision allow the purchaser to access the information on the share unit factor for their unit and the amount of maintenance fees that would be charged on them upon the purchase. This is benefit to owner and purchaser as it will be easy to determine maintenance charges, sinking fund and other outgoing for all residents including developer's unsold units (10).

\section{Conclusion}

In a nutshell, the late issuance of Strata Title is one of the main issues related to stratified residential buildings. This research explains the provision of the latest SMA 2013, Act 757 on implementation of the new Share Unit formula to obtain SiFUS and Strata Title procedures and the implication to buyers and unit owners. Later, the implication and benefit of the new provision and regulation will be justified by using frequency distribution. As a results, the new provision require many related professional such as Architect, Land Surveyor, developer, etc to involve and understand the overall procedure as to ensure accuracy and to avoid misleading to the implementation. The crucial part is where the new formula will be used to get the approved certificate, SiFUS before issuance of Strata Title by The Land Office. The calculation of the share unit have to be accurate and true following the land office and Jupem approval before proceed. Without the issuance of SiFUS certificate, the next process would not be continued thus the development would not proceed. The implication result of the new provision can be established as a guide to determine the realistic of the new enforcement of the SMA 2013, Act 757 and STA 1985, Act 318 as to solve the late issuance of Strata Title to purchaser, fraud cases by developer and project abandonment from it root causes and to ensure the interest of future buyers and unit owners are protected thus the Strata Title guaranteed to be delivered to them as promised.

\section{References}

[1] STA 1985. ACT 318: THE COMMISSIONER OF LAW REVISION, MALAYSIA; 2006

[2] Khalid MS, Ahmad AH, Zakaria R, Arshad R, Pon Y. Towards Strengthening Building Maintenance and Management by Joint Management Bodies (Jmb) in High Rise/Stratified Housing in Malaysia. International Journal of Social Science and Humanity. 2017;7(4):239.

[3] Azmin N. The study of problems faced by property management in managing the high rise condominium in Malaysia. Master's Thesis, Universiti Teknologi Malaysia, Malaysia. 2006.

[4] Kamaruzzaman SN, Muhamad Salleh N, AlZawawi S. Assessment on problems of issuances and transferences of Strata title in Malaysia: The perception of the owner. 2010.

[5] Tawil N, Che-Ani A, Ramly A, Daud M, Abdullah N. Service charge issue in Malaysian high-rise residential management: An analysis using a fuzzy conjoint model. International Journal of Physical Sciences. 2011;6(3):441-7.

[6] SMA. ACT 757: PERCETAKAN NASIONAL MALAYSIA BERHAD; 2013.

[7] Tawil NM, Yusoff YM, Che-Ani A, Abdullah N, Surat M. A Study of Management Corporation Financial in High Rise Residential with Correlation of Management Fund and Facilities Provided. International Business Management. 2012;6(3):304-7.

[8] Kaedah-Kaedah Hakmilik Strata Warta Kerajaan Persekutuan, Jabatan Peguam Negara. 2015.

[9] Mohd I, Arbin E, Ramly A. Urban housing development: town planning issues. PLANNING MALAYSIA JOURNAL. 2007;5(1).

[10] Processes on SiFUS \& Strata Title. REDHA Version 022016. 
[11] Naoum SG. Dissertation research and writing for construction students: Routledge; 2012.

[12] Rabiee F. Focus-group interview and data analysis. Proceedings of the nutrition society. 2004;63(4):655-60.

[13] Bhattacherjee A. Social science research: Principles, methods, and practices. 2012.

[14] Nicole Tan Sm. The Malaysian Bar, problem faced by owners of strata title properties Malaysia: The sun 2007.
[15] Tiun LT. Managing high-rise residential building in Malaysia: where are we?2006.

[16] Hussin KB, Pardi FBH, editors. APARTMENT LAW IN MALAYSIA BUYING PROPERTIES WITHOUT TITLE: LEGAL POINT OF VIEW. International Convention on Urban Development and Management, 7-9 July: Langkawi; 2003. 